\title{
Light quality in micropropagation of Eucalyptus grandis $\times$ Eucalyptus urophylla
}

\author{
Qualidade de luz na micropropagação de Eucalytpus grandis $\times$ Eucalyptus \\ urophylla
}

Denys Matheus Santana Costa Souza ${ }^{1}$ (D), Sérgio Bruno Fernandes ${ }^{1}$ (D), Maria Lopes Martins Avelar ${ }^{1}$ (D),

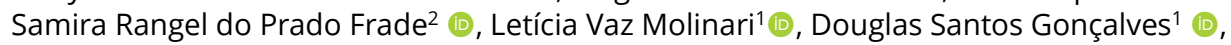
José Eduardo Brasil Pereira Pinto ${ }^{1}$ (D) Gilvano Ebling Brondani ${ }^{1}$ (B)

${ }^{1}$ Universidade Federal de Lavras - UFLA, Lavras, MG, Brasil

2Universidade Estadual Paulista - UNESP, Ilha Solteira, SP, Brasil

How to cite: Souza, D. M. S. C., Fernandes, S. B., Avelar, M. L. M., Frade, S. R. P., Molinari, L. V., Gonçalves, D. S., Pinto, J. E. B. P., Brondani, G. E. (2020). Light quality in micropropagation of Eucalyptus grandis $\times$ Eucalyptus urophylla. Scientia Forestalis, 48(127), e3329. https://doi.org/10.18671/scifor.v48n127.03

\begin{abstract}
The importance of eucalypts species and their interspecific hybrids has been evidenced in forestry programmes due to their wood quality and adaptation to diverse environmental conditions. To solve the limiting factors in the in vitro cultivation of the A211 clone of Eucalyptus grandis Hill ex Maiden $\times$ Eucalyptus urophylla S. T. Blake, the aim of the study was to evaluate the light quality on in vitro establishment, multiplication, elongation and rooting stages. The tissues used to obtain explants were nodal segments derived from ministumps of the A211 clone. The effects of light quality on in vitro establishment, multiplication, elongation and rooting were evaluated using five sources (fluorescent lamp, white LEDs, red LEDs, blue LEDs and red/blue LEDs). At 30 days, the percentage of contamination and non-responsive explants, length and number of shoots per explant, oxidation, shoot vigor, pigment content, leaf anatomy, root length and number of roots per explant were evaluated. Fluorescent lamps and red/blue LEDs are more suitable for use in the in vitro establishment, multiplication, elongation and rooting of the A211 clone, without hindering the development of shoots for the production of micropropagated clonal plants.
\end{abstract}

Keywords: In vitro propagation; Wave-length; LEDs, Cloning.

\section{Resumo}

A importância das espécies de eucalipto e de seus híbridos interespecíficos tem sido evidenciada nos programas de silvicultura, devido à qualidade da madeira e adaptação a diversas condições ambientais. Para solucionar os fatores limitantes ao cultivo in vitro do clone A211 de Eucalyptus grandis Hill ex Maiden $\times$ Eucalyptus urophylla S. T. Blake, o presente trabalho teve como objetivo avaliar a influência da qualidade de luz nas fases de introdução, multiplicação, alongamento e enraizamento in vitro. Os tecidos utilizados para a obtenção dos explantes foram segmentos nodais, provenientes de minicepas do clone A211 de $E$. grandis $\times E$. urophylla. Os efeitos no cultivo in vitro foram avaliados por meio de cinco fontes de qualidade de luz (Lâmpada fluorescente, LEDs branco, LEDs vermelho, LEDs azul e LEDs vermelho/azul). Dados de porcentagem de contaminação e explantes não responsivos, comprimento e número de brotos por explante, oxidação, vigor das brotações, conteúdo de pigmentos, anatomia foliar, comprimento e número de raízes por explante foram coletados aos 30 dias de cultivo in vitro. Com base nos resultados obtidos, pôde-se inferir que as lâmpadas fluorescentes e LEDs vermelho/azul são as mais adequadas para serem utilizadas na introdução, multiplicação, alongamento e enraizamento in vitro do clone A211 de E. grandis $\times$ E. urophylla, não ocasionando prejuízos no desenvolvimento de brotações destinadas à produção de plantas clonais micropropagadas.

Palavras-chave: Propagação in vitro; Comprimento de onda; LEDs, Clonagem.

Financial support: We thank the National Counsel of Technological and Scientific Development (CNPq), Coordination for Improvement of Higher Education Personnel (CAPES) and Research Support Foundation of the State of Minas Gerais (FAPEMIG) for the financial support and scholarship. Conflict of interest: nothing to declare.

Correspondig author: gilvano.brondani@ufla.br

Received: 05 abril 2019.

Accepted: 02 agosto 2019.

Editor: Paulo Henrique Müller Silva. 


\section{INTRODUCTION}

The expansion of forest plantations to non-traditional regions and the search for improved plant production have increased the use of species and hybrid combinations. The hybridization of Eucalyptus grandis with Eucalyptus urophylla has provided excellent results in wood quality and growth, in addition to providing better environmental adaptation and easier vegetative propagation (Assis et al., 2018; Trueman et al., 2018). In recent years, research on the micropropagation of E. grandis, E. urophylla and their hybrids has increased and has included the in vitro establishment (Keret et al., 2018), multiplication (Trueman et al., 2018), elongation (Gallo et al., 2017), rooting and acclimatization stages (Brondani et al., 2018).

To understand the limiting factors of each stage of in vitro cultivation, it is necessary to conduct basic studies to maximize the production of microstumps. Several technologies have been proposed to automate the micropropagation process, including innovations in the culture environment such as alternative containers that allow gas exchange, use of bioreactors, new LED light sources, and automation of culture systems and routine procedures, such as medium preparation, transplant and acclimatization (Brondani et al., 2018; Batista et al., 2018; Souza et al., 2019).

Recent studies report how different wavelengths influence plant metabolism. According to Batista et al. (2018), blue light (450 - $495 \mathrm{~nm})$, red light (620 - $750 \mathrm{~nm})$, far-red light $(750-850 \mathrm{~nm})$ and green light $(495-570 \mathrm{~nm})$ influence the in vitro morphogenesis of the plant. In addition to its role in photosynthetic processes, light can act as an external regulation factor in several morphogenic and physiological processes that alter the architecture and phytochemical levels of the plant (Ouzounis et al., 2015). Studies on the effect of different wavelengths of LED lamps on morphogenesis and growth are still scarce for eucalypts species.

Given the need to adapt micropropagation for E. grandis $\times$ E. urophylla A211 clone, this study aimed to evaluate the effect of light quality on in vitro establishment, multiplication, elongation and rooting stages.

\section{MATERIAL AND METHODS}

\section{Study site and experimental material}

The experiments were conducted at the Tissue Culture Laboratory of the Department of Agriculture (DAG), Federal University of Lavras - UFLA, Lavras, Minas Gerais (MG), Brazil. The material used to obtain the explants originated from ministumps of the A211 clone of Eucalyptus grandis Hill ex Maiden $\times$ Eucalyptus urophylla S. T. Blake. They were provided by the 'Viveiro Esteio Produção de Mudas' company, located in the municipality of São João Del Rei MG, Brazil.

The ministumps were established in UFLA's Department of Forestry Sciences Forest Nursery in a gutter for the clonal mini-garden system containing sand substrate, under a semi-hydroponic system with nutrient solution dripping four times a day at a total flow rate of $4 \mathrm{~L} \mathrm{~m}^{-2}$ day.

\section{Collection of shoots and preparation of explants}

Nodal segments $(3-4 \mathrm{~cm}$ ) sectioned from the third and fourth terminal nodes of the shoots were collected 20 days after pruning the ministump apex. Subsequently, the explants were immersed in deionized and autoclaved water and transported to the tissue culture laboratory for the in vitro inoculation step.

\section{In vitro establishment}

The nodal segments were washed in running water and immersed in a fungal solution containing $2.4 \mathrm{~g} \mathrm{~L}^{-1}$ of Orthocide $500^{\circledR}$ (50\% Captan as active principle) for 15 minutes. Next, the explants were washed five times in autoclaved deionized water and immersed in $70 \%$ 
alcohol solution ( $\mathrm{v} / \mathrm{v})$ for 30 seconds with constant agitation inside a horizontal laminar flow cabinet. Then, they were immersed in $1 \% \mathrm{NaClO}(\mathrm{v} / \mathrm{v}) \mathrm{Clarix}^{\circledR}$ solution for 15 minutes. Finally, the nodal segments were washed in autoclaved deionized water five times, and the explants were prepared and inoculated vertically under aseptic conditions in test tubes $(25 \times 150 \mathrm{~mm})$ containing $10 \mathrm{~mL}$ of the culture medium.

The basic culture medium used in the experiments was the saline MS formulation (Murashige \& Skoog, 1962) supplemented with $30 \mathrm{~g} \mathrm{~L}^{-1}$ of sucrose (Synth Ltda) and $6 \mathrm{~g} \mathrm{~L}^{-1}$ of agar (Merck SA). The pH was adjusted to $5.8 \pm 0.05$. The culture media was autoclaved at $127^{\circ} \mathrm{C}$ and pressure of $1.5 \mathrm{kgf} \mathrm{cm}^{-2}$ for 20 minutes. The explants were kept in a growth room at a temperature of $24 \pm 1{ }^{\circ} \mathrm{C}$, a photoperiod of 16 hours of light and irradiance of $40 \mu \mathrm{mol} \mathrm{m}^{-2} \mathrm{~s}^{-1}$ (quantified by radiometer, LI-COR ${ }^{\circledR}, \mathrm{LI}-250 \mathrm{~A}$ Light Metre) using different light sources.

The data on mean contamination percentage (fungal and/or bacterial), non-responsive explants, oxidation and vigor were evaluated according to the scoring scale proposed by Oliveira et al. (2016) (Figure 1A-F), and the length of shoots larger than $0.5 \mathrm{~cm}$ and mean number of shoots per explant greater than $0.5 \mathrm{~cm}$ were evaluated 30 days after inoculation.

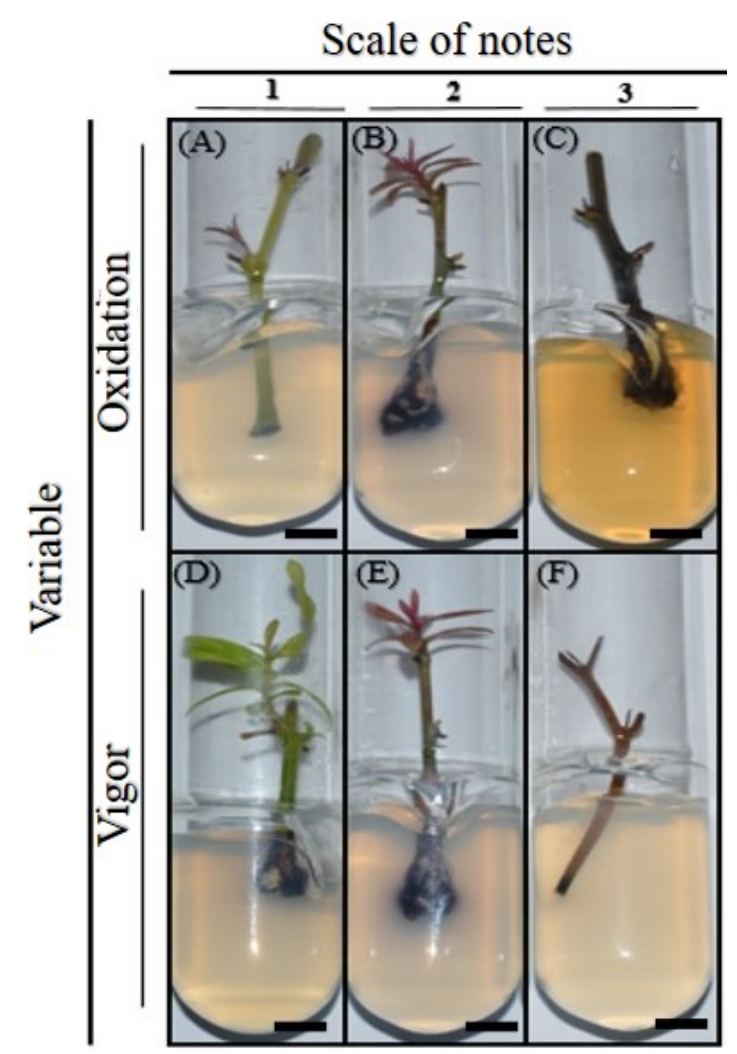

Figure 1. Oxidation and vigor assessments according to a scale of notes. (A) OXI 1 = Null: no oxidation; (B) OXI 2 = Average: reduced oxidation at the base of the explants medium with grayish tonality; (C) OXI 3 = High: complete oxidation of shoots); (D) VIG 1 = Optimum: induction of shoots with active growth, without apparent nutritional deficiency; (E) VIG 2 = Good: induction of shoots, but with leaves of reduced size; (F) VIG 3 = Low: no induction of shoots and, senescence and death.

\section{In vitro multiplication}

Shoots $( \pm 0.5 \mathrm{~cm})$ produced during the in vitro establishment stage were subcultured into test tubes $(25 \mathrm{~mm} \times 150 \mathrm{~mm}$ ) containing $10 \mathrm{~mL}$ of MS culture medium supplemented with $2.22 \mu \mathrm{M}$ of 6-benzylaminopurine - Sigma ${ }^{\circledR}$ (BAP), $0.05 \mu \mathrm{M}$ of naphthaleneacetic acid - Sigma ${ }^{\circledR}$ (NAA) and $6 \mathrm{~g} \mathrm{~L}^{-1}$ of agar.

Data on oxidation, vigor, shoot length $(>0.5 \mathrm{~cm})$, mean number of shoots per explant $(>0.5 \mathrm{~cm})$ and photosynthetic pigments were collected at 30 days of culture. 


\section{In vitro elongation and rooting}

The shoots produced in the in vitro multiplication stage were prepared by isolating four standard shoots of $0.5 \mathrm{~cm}$ and inoculated under aseptic conditions in glass flasks $(250 \mathrm{~mL}$ capacity). Shoots were grown for 30 days in flasks containing $50 \mathrm{~mL}$ of MS culture medium supplemented with $0.22 \mu \mathrm{M}$ of BAP and $2.46 \mu \mathrm{M}$ of indole-3-butyric acid - Sigma® (IBA), $30 \mathrm{~g} \mathrm{~L}^{-1}$ of sucrose, and $6 \mathrm{~g} \mathrm{~L}^{-1}$ of agar.

Data on mean oxidation and vigor according to a scoring scale, shoot length $(>0.5 \mathrm{~cm})$, mean number of shoots per explant $(>0.5 \mathrm{~cm})$, number of roots and length of the longest root $(\mathrm{cm})$ were collected at 30 days of culture.

\section{Light quality}

A spectrophotometer (Ocean Optics Spectra-Suite) was used for the analysis of the variations of absolute irradiance $\left(\mu \mathrm{W} \mathrm{cm} \mathrm{cm}^{-2} \mathrm{~nm}^{-1}\right)$ and the wavelength $(\mathrm{nm})$ of light emitted by the different types of lamps. That data was then used to plot the different light spectra in graphs (Figure 2A-E).
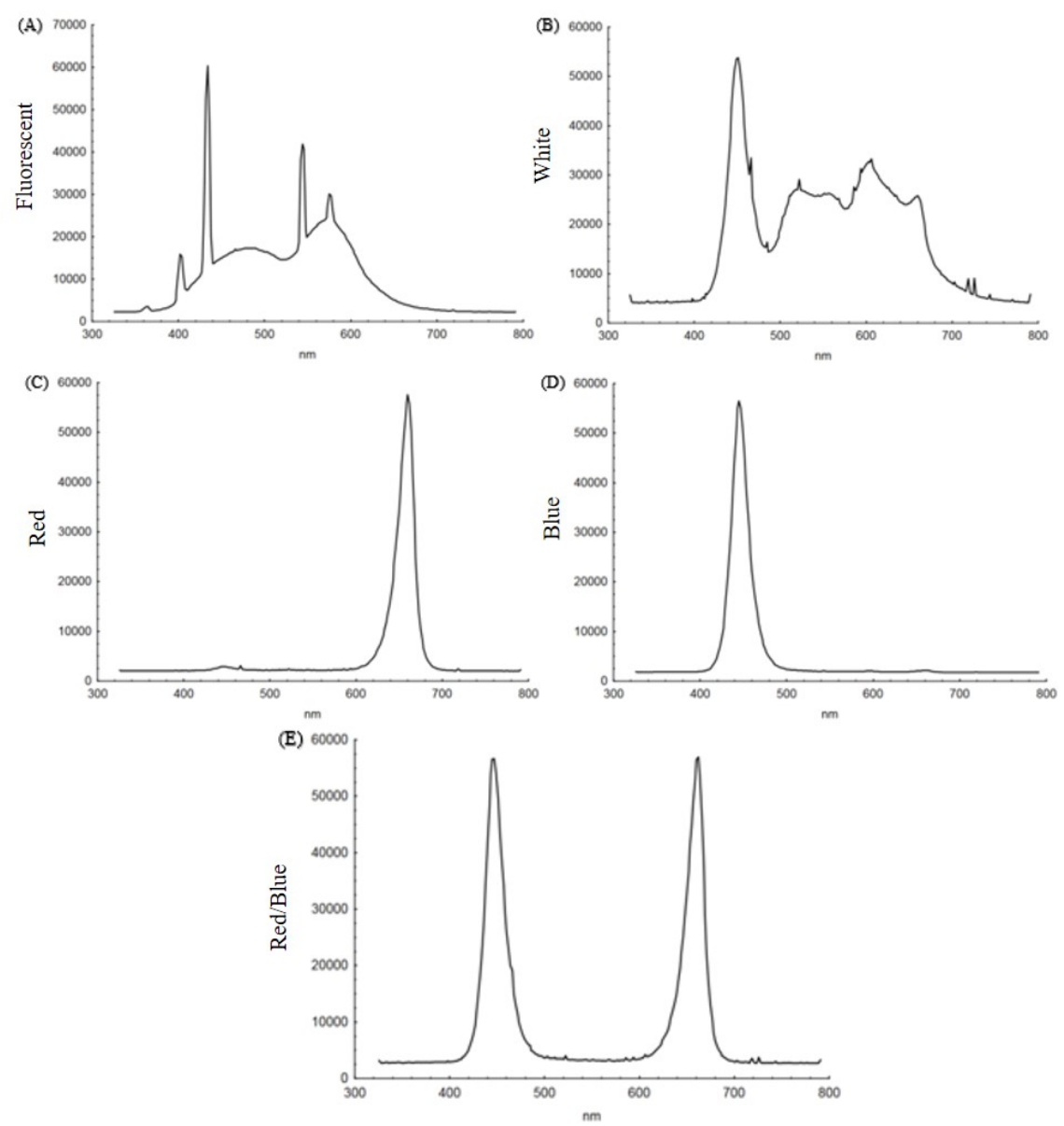

Figure 2. Variations of absolute irradiance $\left(\mu \mathrm{W} \mathrm{cm} \mathrm{cm}^{-2} \mathrm{~nm}^{-1}\right)$ and wavelength ( $\mathrm{nm}$ ) of light emitted by: (A) Fluorescent lamp; (B) White LEDs; (C) Red LEDs; (D) Blue LEDs; (E) 1:1 Red/Blue LEDs used in the in vitro condition of the hybrid clone A211 of E. grandis $\times$ E. urophylla.

\section{Photosynthetic pigment analysis}

Leaf discs (i.e., $25 \mathrm{mg}$ of leaf fresh matter) were sampled from shoots of the in vitro multiplication assay after 30 days under the different light sources and inoculated in $5 \mathrm{~mL}$ of DMSO solution (Sigma Aldrich) for 48 hours in the dark (Lichtenthaler, 1987). The absorbance of the samples was determined in triplicate in a quartz cuvette with a $10 \mathrm{~mm}$ pathlength in a Genesys 10UV spectrophotometer (ThermoScientific, USA). 


\section{Leaf anatomy}

Representative samples of leaves from each treatment were collected and kept for 48 hours in $70 \%$ formaldehyde acetic acid solution, followed by a transfer to $70 \%$ ethanol and a graded ethanol series (80, 90 and 100\%) and kept for 30 minutes in each solution (Johansen, 1940). Then, the samples were transferred to a $100 \%$ alcohol solution and historesin (Leica ${ }^{\circledR}$ ) in a 1:1 ratio in a hot oven (overnight). The embedding was performed with pure hydroxyethyl methacrylate resin, and $7 \mathrm{~mm}$ cross sections were obtained with a manual rotary microtome and a knife. The tissues were stained with toluidine blue, mounted on histological slides, and photomicrographed with a coupled digital camera (AxionCam ERc5s) on a micrometre scale and $20 x$ and $40 x$ objectives.

\section{Experimental design and data analysis}

In vitro establishment, multiplication, elongation and rooting stages were arranged in a completely randomized design with five different light sources: fluorescent lamp - L/F (HO Sylvania T12, 110 W, São Paulo, Brazil), white LED lamp - L/W (SMD 100, 18 W, Vilux®, Vitória, ES, Brazil), red LED lamp - L/R (LabPARLL-HR/DB-480, 11.6 W, LabLumens ${ }^{\circledR}$, Carapicuíba, SP, Brazil), Blue LED lamp - L/B (LabPARLL-HR/DB-480, 11.6 W, LabLumens ${ }^{\circledR}$, Carapicuíba, SP, Brazil) and 1:1 red/blue LEDs lamp - R/B (LabPARLL-HR/DB- 480, $11.6 \mathrm{~W}$, LabLumens ${ }^{\circledR}$, Carapicuíba, SP, Brazil). Thirty samples/replicates of one explant each were used for the establishment and multiplication. Twelve samples/replicates, consisting of four explants each, were used for in vitro elongation and rooting.

The analyses were processed with the R Core Team software, 2018, using the ExpDes package, version 1.1.2 (Ferreira et al., 2013). The data were subjected to analysis of variance (ANOVA) with Tukey's test at 5\% significance level.

\section{RESULTS AND DISCUSSION}

\section{Effect of light quality on in vitro establishment}

The appearance of the E. grandis $\times$ E. urophylla A211 clone explants, according to the studied characteristics, can be observed in Figure 3A-D.

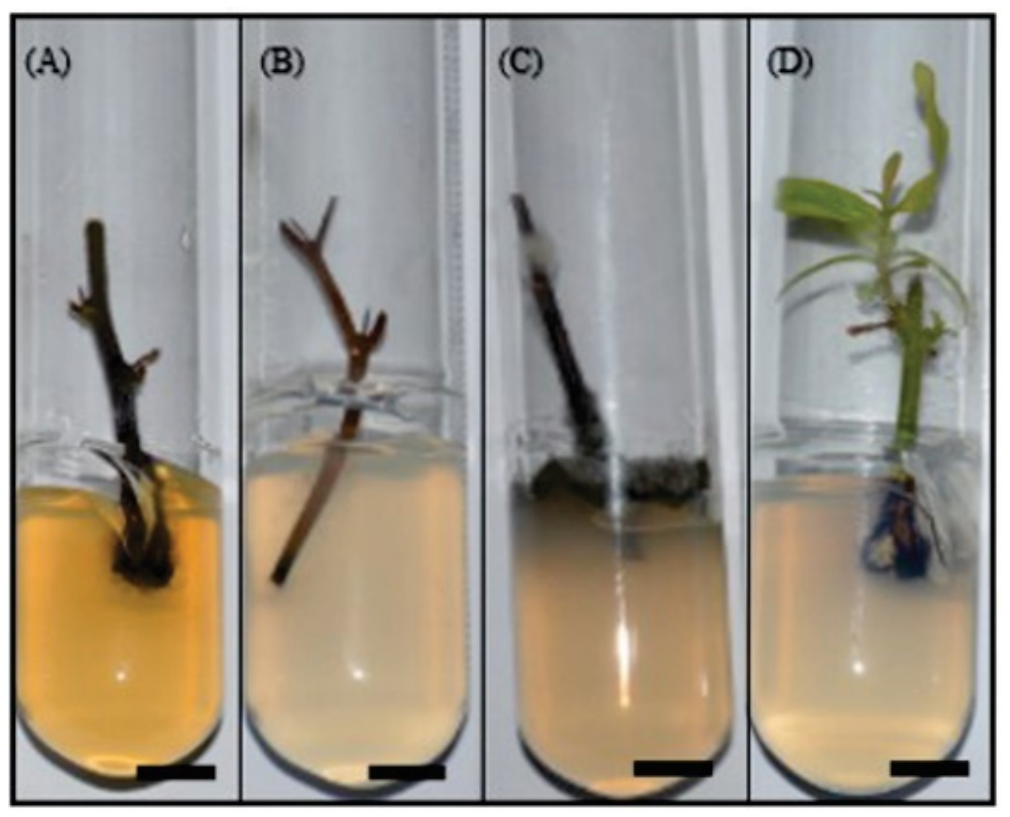

Figure 3. Explants of $E$. grandis $\times E$. urophylla clone $A 211$, at 30 days after inoculation on in vitro condition: (A) Oxidized explant; (B) Non responsive explant; (C) Explant contaminated; (D) Reactive explant. Bar $=0.5 \mathrm{~cm}$. 
The different light sources used in the in vitro culture of A211 clone explants influenced the percentage of contamination at 30 days after inoculation (Figure 4A). The lowest mean contamination occurred with the use of the R/B source (6.6\%) but did not differ from the use of separate L/R and L/B lights $(p<0.05)$. Most likely, this result may be related to the metabolic pathway of microorganisms given that the fungi are receptors of the blue and red wavelengths, absorbing photons into the cells, regulating the fungal photoresponses by differential genetic expression in the carotenoid biosynthesis and hyphae aggregation (Postemsky \& Curvetto, 2016).

Low percentages of explants without shoots were observed mainly with light source L/F (mean of 3.3\%) (Figure 4B). In an E. urophylla $\times$ E. globulus hybrid, it was possible to obtain $95 \%$ of explants with shoots using the fluorescent lamp (Borges et al., 2011). Oliveira et al. (2015) found $51.2 \%$ of explants with shoots in Eucalyptus cloeziana. Thus, the establishment of tissues during the in vitro establishment stage may depend on the plant material (genotype) and on the culture conditions used, such as the light quality in the growth room.
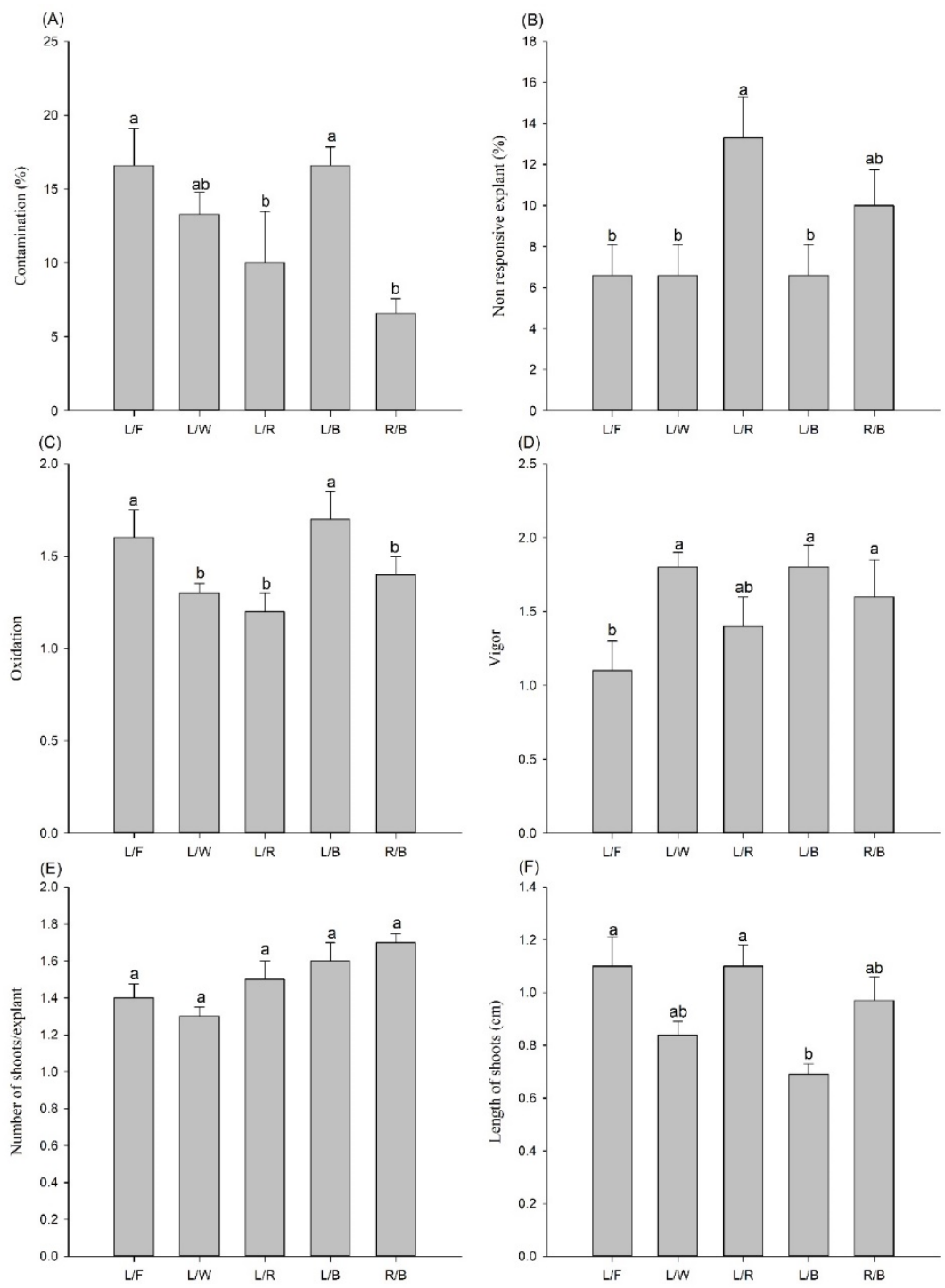

Figure 4. Characteristics observed on in vitro introduction of E. grandis $\times$ E. urophylla clone A211 under qualities of light [Fluorescent lamp (L/F), White LEDs (L/W), Red LEDs (L/R), Blue LEDs (L/B) and Red/Blue LEDs (R/B)]. (A) Percentage of contamination; (B) Percentage non responsive explant; C-D: Scale of notes (Figure 1): (C) Oxidation; (D) Vigor; (E) Number of shoots per explant; (F) Length of shoots (cm).

* Means followed by the same letter do not differ from each other, by the Tukey test at $5 \%$ of significance. Bars represent standard deviation. 
The oxidation and vigor, according to the scoring scale, showed the lowest means in the light sources L/F, L/W, L/R and R/B, with a significant difference $(p<0.05)$ for the L/B (Figure $4 C$ and 4D). These results are close to those found by Souza et al. (2018), who observed low phenolic oxidation and good vigor of the explants in the in vitro establishment of Corymbia citriodora $\times$ C. torelliana.

Phenolic oxidation has been a problem associated with the micropropagation of woody species, especially when considering the in vitro establishment stage, which may influence culture growth. These results may be related to culture factors, such as flask size (with smaller flasks leading to low carbon dioxide concentrations and high ethylene concentrations), light intensity, air temperature and relative humidity (Xiao et al., 2011).

The number of shoots, explants under the light source R/B had a higher mean (1.7 shoots) but showed no significant difference for the other treatments $(p>0.05)$ (Figure 4E). The combination of red and blue lights using LED lamps resulted in a higher number of shoots per explant in Acer saccharum (Singh et al., 2017), indicating the importance of this light combination for in vitro culture.

Regarding the shoot length, it was found that the light quality also affected the development of the explants with significant changes in shoot growth. The L/F and L/R sources promoted higher mean length $(1.1 \mathrm{~cm})$ and differed from the L/B light source (Figure 4F). Lightemitting diodes (LEDs) are alternative light sources due to their wavelength specificity, low amount of heat produced, low degradation and high durability, which benefits in vitro culture and reduces costs when compared to fluorescent lamps (Bugbee, 2016). However, the fluorescent light also favored the development of A211 clone explants under in vitro conditions.

\section{Effect of light quality on in vitro multiplication}

The different light sources influenced oxidation of the tissues, with a lower mean score (1.1) for the L/W source, differing $(p<0.05)$ only from the L/B source (Figure 5A). The lowest mean shoot vigor score (1.2) was observed with the L/F light source (Figure 5B), resulting in tissue growth and the absence of nutritional deficiency, according to the scoring scale. Using a fluorescent lamp in the in vitro multiplication stage of $E$. cloeziana, by Oliveira et al. (2015), found similar results when considering the scoring scale for the classification of shoot vigor.

For the number of shoots per explant, equal mean values (9.3 shoots) were observed using the light sources R/B and L/F; however, they differ significantly $(p<0.05)$ from the L/B treatment (Figure $5 C$ ). Likewise, the R/B and L/F sources promoted similar mean shoot lengths $(\sim 1.7 \mathrm{~cm})$ and differed $(p<0.05)$ from the L/W, L/R and L/B sources (Figure 5D). The data in the literature corroborate those found in the present study because the combination of red/blue LEDs in Populus euramericana induced a greater number and length of shoots (Kwon et al., 2015). Batista et al. (2018) confirmed the superiority of LED lamps in the in vitro development of plants when compared to fluorescent lamps.

The amounts of chlorophyll $a, b$ and carotenoids were influenced by the different light qualities (Figure 5E). The results indicate that the light sources L/F, R/B and L/W generated higher amounts of the aforementioned photosynthetic pigments. The biosynthesis of chlorophyll a, b and carotenoids is influenced by the quality and intensity of emitted light, with greater efficiency of the photosynthetic process predominantly in the combined blue and red wavelengths (Dutta Gupta \& Karmakar, 2017).

Higher levels of chlorophyll $a$ and $b$ were observed in the in vitro multiplication of Gerbera jamesonii under red/blue LED light compared to separate blue and red LED lights (Pawłowska et al., 2018). In Stevia rebaudiana, the amounts of carotenoids in shoots exposed to red/blue LED light were higher compared to blue LED light (Ramírez-Mosqueda et al., 2017). 

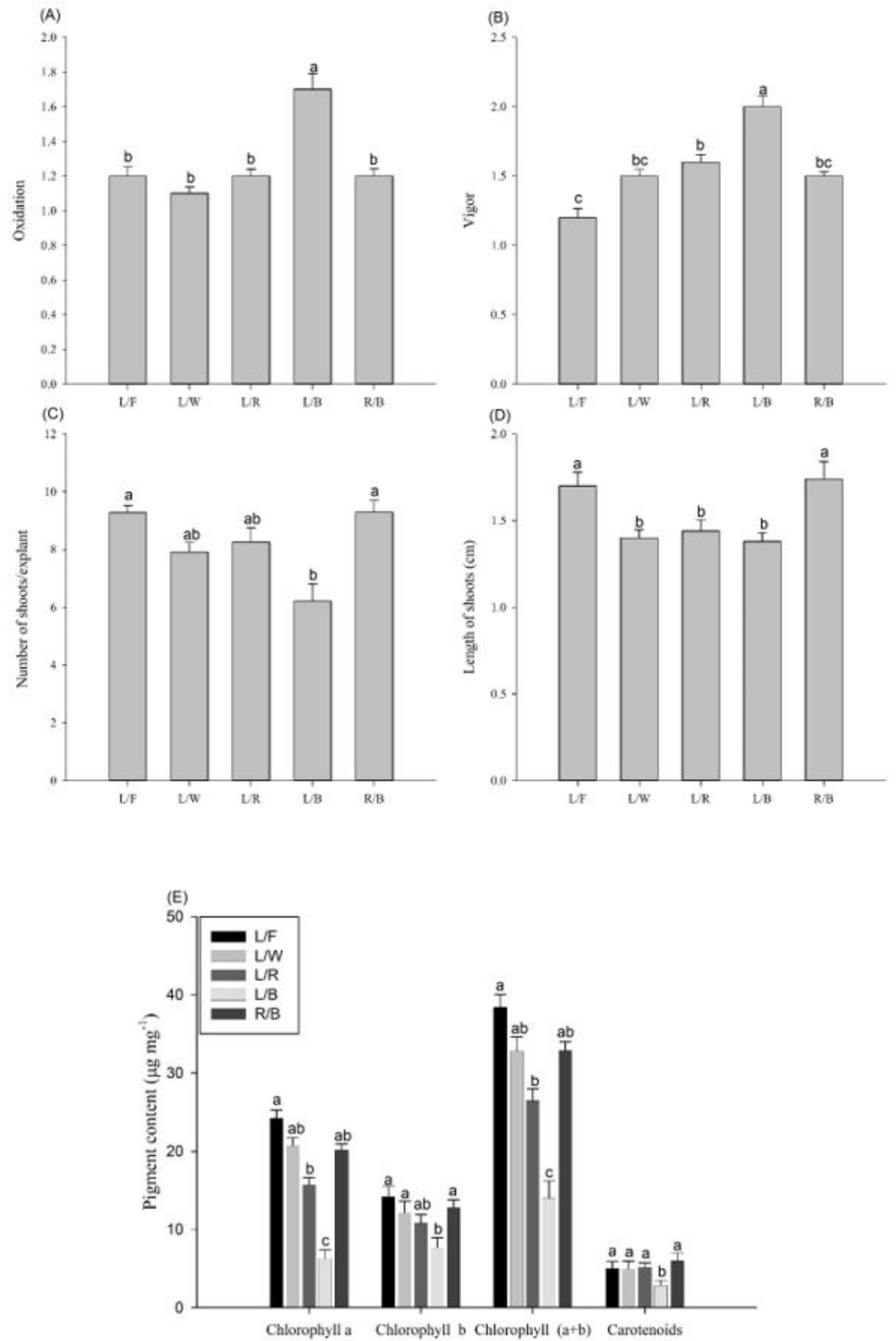

Figure 5. Characteristics observed on in vitro multiplication of E. grandis $\times$ E. urophylla clone A211 under qualities of light [Fluorescent lamp (L/F), White LEDs (L/W), Red LEDs (L/R), Blue LEDs (L/B) and Red/Blue LEDs (R/B)]. A-B: Scale of notes: (A) Oxidation; (B) Vigor; (C) Number of shoots per explant; (D) Length of shoots (cm); (E) Pigment content. *Means followed by the same letter do not differ from each other by the Tukey test at $5 \%$ of significance. Bars represent standard deviation.

\section{Effect of light quality on in vitro elongation and rooting}

Regarding the in vitro elongation of shoots, the L/F light sources produced the best results for mean length $(7.2 \mathrm{~cm}$ ) and vigor (1.2) of shoots (Figure 6B and 6D), differing significantly $(p<0.05)$ for light sources $L / R$ and L/B. Similar results using a fluorescent lamp source were observed for Abies borisii-regis explants (Smirnakou et al., 2016). The adverse effect of the light spectrum (450 nm to $500 \mathrm{~nm}$ ) may inhibit stem elongation (Taiz \& Zeiger, 2013). 
Regarding the mean oxidation score (1.1), R/B showed the lowest mean values but did not differ statistically $(p>0.05)$ from the other treatments (Figure $6 \mathrm{~A})$. For the mean number of shoots, R/B had the best morphogenetic responses under in vitro cultivation (Figure 6C), differing significantly $(p<0.05)$ for the L/W light source.

The control of LED light quality during plant culture is important because it can optimize the photosynthetic rate and increase shoot production (Silva et al., 2017). However, light can also influence the concentrations of plant growth regulators, acting as a morphogenic signal for the proliferation of shoots, whereas the early stages in the light-signalling pathway involve the activation of cytokinins (Roman et al., 2016).
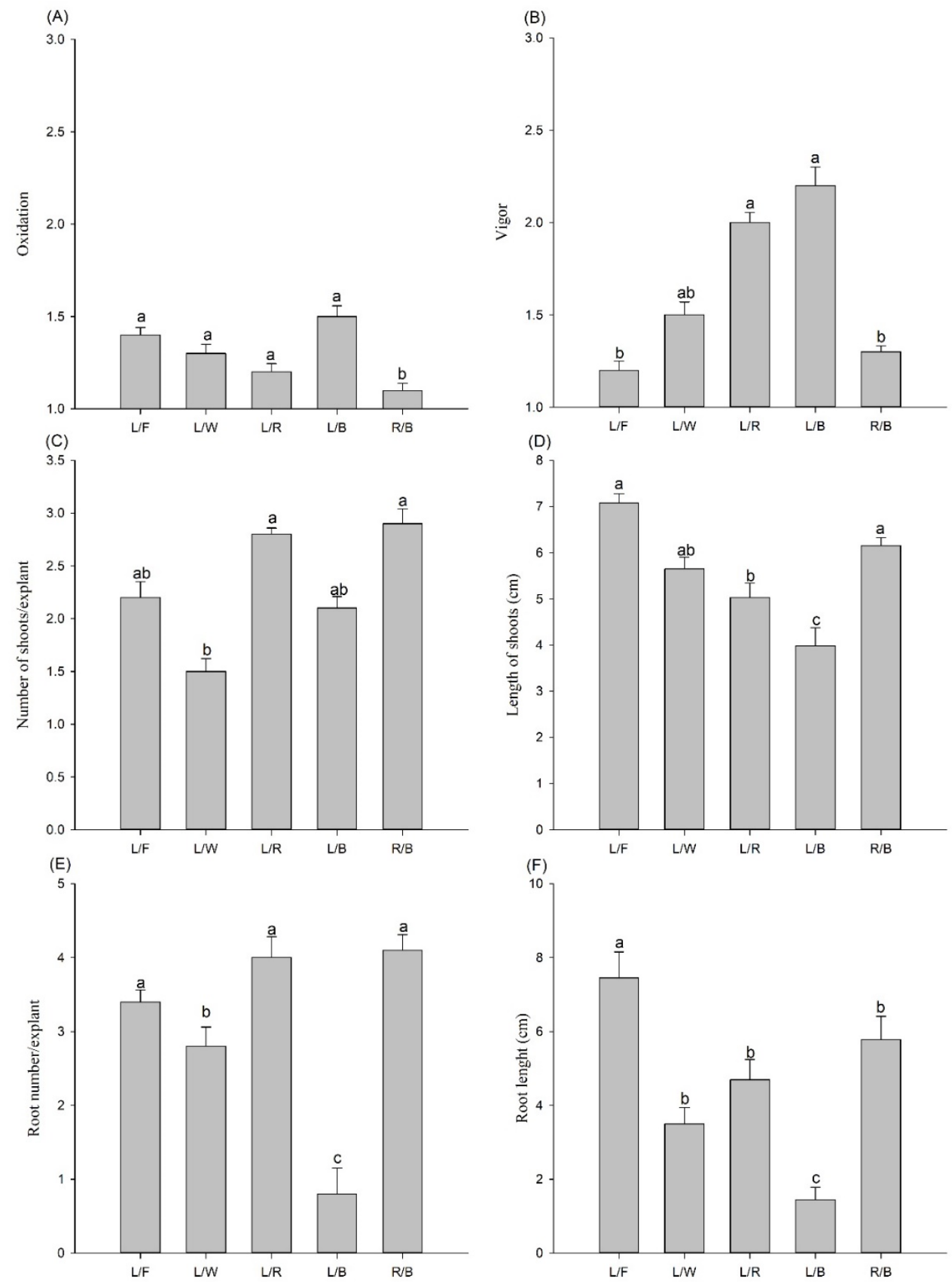

Figure 6. Characteristics observed on in vitro elongation of $E$. grandis $\times E$. urophylla clone $A 211$ under qualities of light [Fluorescent lamp (L/F), White LEDs (L/W), Red LEDs (L/R), Blue LEDs (L/B) and Red/Blue LEDs (R/B)]. A-B: Scale of notes (Figure 1): (A) Oxidation; (B) Vigor; (C) Number of shoots per explant; (D) Length of shoots (cm); (E) Root number per explant; (F) Root length (cm) * Means followed by the same letter do not differ from each other, by the Tukey test at $5 \%$ of significance. Bars represent standard deviation. 
Regarding the root system of microcuttings, the use of R/B provided a higher mean number of roots (4.1), with a significant difference for L/W and L/B (Figure 6E). Similar results were found in Microlaelia lundii microcuttings, where the main advantages were the increase in rooting percentage, number of roots and survival percentage (Favetta et al., 2017). Regarding the mean length of the longest root per microcutting, the use of $L / F(7.6 \mathrm{~cm})$ was superior to the other treatments (Figure 6F). Similar results were observed in Populus americana microcuttings (Kwon et al., 2015).

Understanding the relationship between wavelengths and plant growth regulators under in vitro culture enables micropropagation protocols to be better defined for the species studied here (Figure 7).

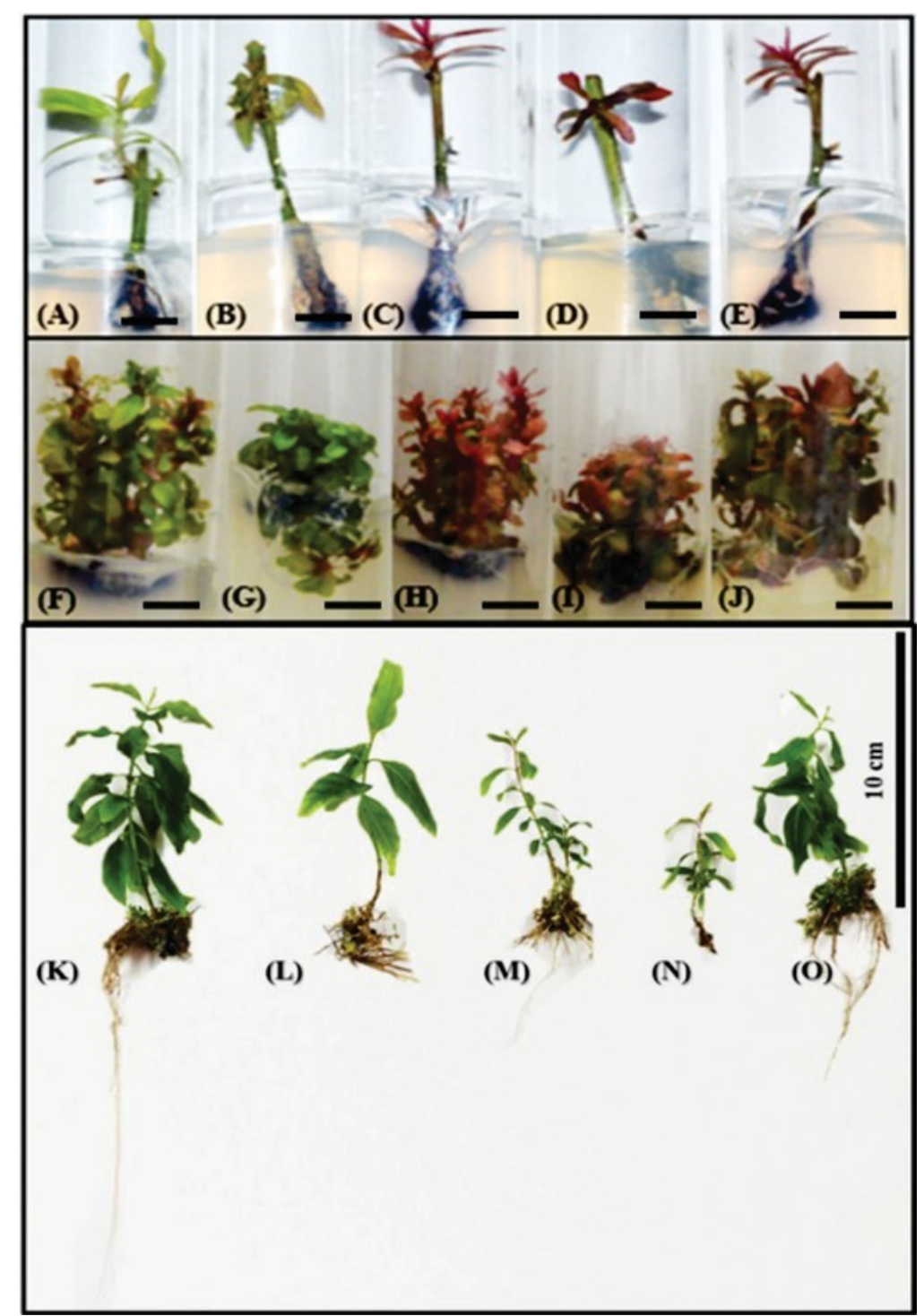

Figure 7. Sprouts of $E$. grandis $\times E$. urophylla clone A211 in vitro cultivated under different light sources.

(A-E): 30 days after inoculation; (F-J): In vitro multiplication; (K-O): In vitro elongation and rooting;

(A, F and K): Fluorescent lamp; (B, G and L) White LEDs; (C, H and $\mathbf{M})$ Red LEDs; (D, I and $\mathbf{N}$ ) Blue LEDs; (E, J and O) Red/Blue LEDs. Bar $=0.5 \mathrm{~cm}$.

Modifications in the structural organization of leaf cells can be observed at the anatomical level when plants are exposed to different light spectra (Figures 8A-C). Greater mesophyll cell development and organization (Figures $8 \mathrm{~A}$ and $8 \mathrm{C}$ ) is observed under $\mathrm{L} / \mathrm{F}$ and $\mathrm{R} / \mathrm{B}$ lights (Figures $8 \mathrm{~A}$ and $8 \mathrm{C}$ ), characterized by a reduction in the volume of intercellular spaces. The opposite can be observed in leaves under L/B light (Figure 8B). 


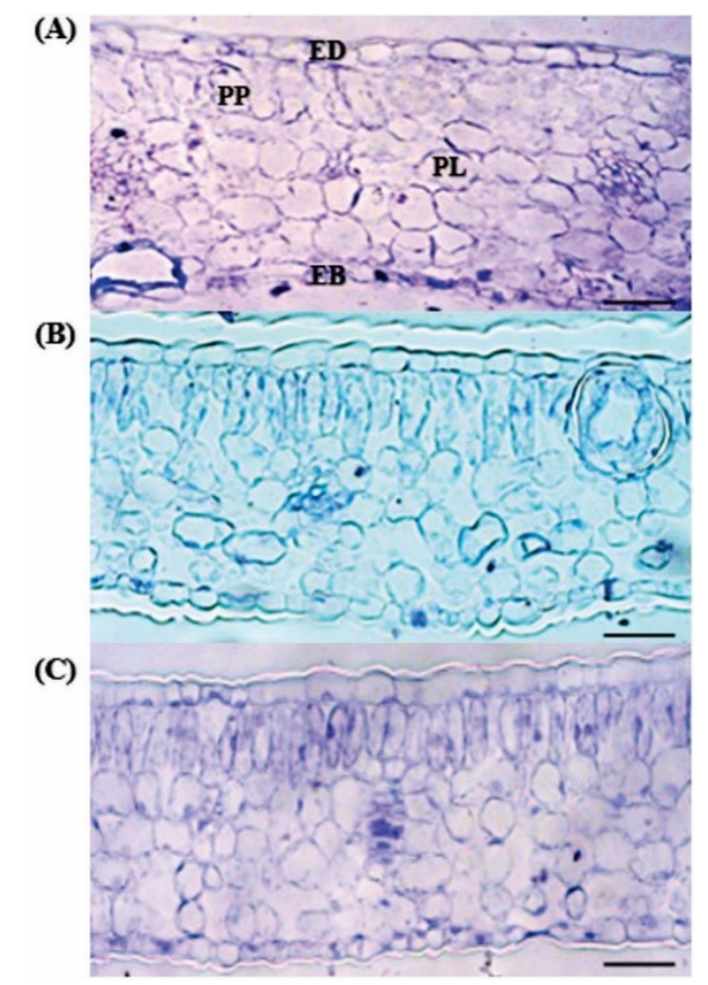

Figure 8. Cross sections of the leaf limb of E. grandis $\times E$. urophylla clone A211 in different light qualities:

(A) Fluorescent lamp; (B) Blue LEDs; (C) Red / blue LEDs. * ED = Adaxial epidermis; PP = Palisade parenchyma; PL = Lacunar parenchyma; EB = Abaxial epidermis. Bar $=200 \mu \mathrm{m}$.

The red spectrum has a strong influence on the development and expansion of mesophyll cells, while the opposite is true for blue light in ornamental plants. In addition, each spectrum is capable of altering expression levels of specific genes involved in the structural organization of plant cells as well as of photosynthetic genes (Fan et al., 2013).

\section{CONCLUSIONS}

The fluorescent and red/blue LED lamps showed the best results in the in vitro establishment, multiplication, elongation and rooting of E. grandis $\times E$. urophylla A211 clone. These two light sources led to lower tissue oxidation, and higher vigor, shoot length, mean number of shoots per explant, photosynthetic pigment content, number of roots and length of the longest root.

\section{ACKNOWLEDGMENT}

We thank the National Council of Technological and Scientific Development (CNPq), Coordination for Improvement of Higher Education Personnel (CAPES) and Research Support Foundation of the State of Minas Gerais (FAPEMIG) for the financial support and scholarship.

\section{REFERENCES}

Assis, C.O., Trugilho, P.F., Goulart, S.L., Assis, M.R., \& Bianchi, M.L. (2018). Efeito da aplicação de nitrogênio na produção e qualidade da madeira e carvão vegetal de um híbrido de Eucalyptus grandis x Eucalyptus urophylla. Floresta e Ambiente, 25(1), 1-8.

Batista, D. S., Felipe, S. H. S., Silva, T. D., Castro, K. M., Mamedes-Rodrigues, T. C., Miranda, N. A., RíosRíos, A. M., Faria, D. V., Fortini, E. A., Chagas, K., Torres-Silva, G., Xavier, A., Arencibia, A. D., \& Otoni, W. C. (2018). Light quality in plant tissue culture: does it matter? In Vitro Cellular \& Developmental Biology. Plant, 54(3), 195-215. http://dx.doi.org/10.1007/s11627-018-9902-5.

Borges, S. R., Xavier, A., Oliveira, L. S., Melo, L. A., \& Rosado, A. M. (2011). Enraizamento de miniestacas de clones híbridos de Eucalyptus globulus. Revista Árvore, 35(3), 425-434. 
Brondani, G. E., Oliveira, L. S., Konzen, E. R., Silva, A. L. L., \& Costa, J. C. (2018). Mini-incubators improve the adventitious rooting performance of Corymbia and Eucalyptus microcuttings according to the environment in which they are conditioned. Anais da Academia Brasileira de Ciências, 90(2, Suppl.1), 2409-2423. PMid:29044323. http://dx.doi.org/10.1590/0001-3765201720170284.

Bugbee, B. (2016). Toward an optimal spectral quality for plant growth and development: the importance of irradiation capture. Acta Horticulturae, (1134), 1-12. http://dx.doi.org/10.17660/ActaHortic.2016.1134.1.

Dutta Gupta, S., \& Karmakar, A. (2017). Machine vision based evaluation of impact of light emitting diodes (LEDs) on shoot regeneration and the effect of spectral quality on phenolic content and antioxidant capacity in Swertia chirata. Journal of Photochemistry and Photobiology. B, Biology, 174, 162-172. PMid:28779689. http://dx.doi.org/10.1016/j.jphotobiol.2017.07.029.

Fan, X. X., Xu, Z. G., Liu, X. Y., Tang, C. M., Wang, L. W., \& Han, X. L. (2013). Effects of light intensity on the growth and leaf development of young tomato plants grown under a combination of red and blue light. Scientia Horticulturae, 153, 50-55. http://dx.doi.org/10.1016/j.scienta.2013.01.017.

Favetta, V., Colombo, R. C., Júnior, J. F. M., \& Faria, R. T. (2017). Light sources and culture media in the in vitro growth of the Brazilian orchid Microlaelia lundii. Ciências Agrárias, 38(4), 1775-1784. http://dx.doi.org/10.5433/1679-0359.2017v38n4p1775.

Ferreira, E. B., Cavalcanti, P. P., \& Nogueira, D.A. (2013). ExpDes: Experimental Designs package. R Package Version, 1(2).

Gallo, R., Xavier, A., Oliveira, B. A., Moura, L. C., Miranda, N. A., Gatti, K. C., \& Otoni, W. C. (2017). Microcutting propagation of Eucalyptus grandis $\times$ Eucalyptus. urophylla through clumps of axillary buds using different containers and substrates. Australian Journal of Crop Science, 11(10), 1327-1333. http://dx.doi.org/10.21475/ajcs.17.11.10.pne607.

Johansen, D. A. (1940). Plant microtechnique. London: McGraw-Hill Book Company. Retrieved in 2019, December 06, from https://krishikosh.egranth.ac.in

Keret, R., Nakhooda, M., \& Hills, P. N. (2018). Optimization of Eucalyptus micropropagation. South African Journal of Botany, 115, 320. http://dx.doi.org/10.1016/j.sajb.2018.02.160.

Kwon, A. R., Cui, H. Y., Lee, H., Shin, H., Kang, K. S., \& Park, S. Y. (2015). Light quality affects shoot regeneration, cell division, and wood formation in elite clones of Populus euramericana. Acta Physiologiae Plantarum, 37(3), 65-74. http://dx.doi.org/10.1007/s11738-015-1812-0.

Lichtenthaler, H. K. (1987). Chlorophylls and carotenoids: pigments of photosynthetic biomembranes. In L. Packer \& R. Douce (Eds.), Methods in enzymology (pp. 350-381). London: Academic. http://dx.doi.org/10.1016/0076-6879(87)48036-1.

Murashige, T., \& Skoog, F. (1962). A revised medium for rapid growth and bioassays with tobacco tissue cultures. Physiologia Plantarum, 15(3), 473-497. http://dx.doi.org/10.1111/j.13993054.1962.tb08052.x.

Oliveira, L. S., Brondani, G. E., Batagin-Piotto, K. D., Calsavara, R., Gonçalves, A. N., \& Almeida, M. (2015). Micropropagation of Eucalyptus cloeziana mature trees. Australian Forestry, 78(4), 219-231. http://dx.doi.org/10.1080/00049158.2015.1073211.

Oliveira, L. S., Xavier, A., Lopes, A. P., Takahashi, E. K., \& Otoni, W. C. (2016). Multiplicação e alongamento in vitro de clones híbridos de Eucalyptus globulus. Ciência Florestal, 26(1), 235-247. http://dx.doi.org/10.5902/1980509821524.

Ouzounis, E., Rosenqvist, C.-O., \& Ottosen, C.-O. (2015). Spectral effects of artificial light on plant physiology and secondary metabolism: a review. HortScience, 50(8), 1128-1135. http://dx.doi.org/10.21273/HORTSCI.50.8.1128.

Pawłowska, B., Żupnik, M., Szewczyk-Taranek, B., \& Cioć, M. (2018). Impact of LED light sources on morphogenesis and levels of photosynthetic pigments in Gerbera jamesonii grown in vitro. Horticulture, Environment and Biotechnology, 59(1), 115-123. http://dx.doi.org/10.1007/s13580-0180012-4.

Postemsky, P. D., \& Curvetto, N. R. (2016). In vitro studies of secondary metabolite-related responses in some species of genus Grifola (Agaricomycetes) from Argentina. International Journal of Medicinal Mushrooms, 18(4), 355-363. PMid:27481302. http://dx.doi.org/10.1615/IntJMedMushrooms.v18.i4.90.

Ramírez-Mosqueda, M. A., Iglesias-Andreu, L. G., \& Bautista-Aguilar, J. R. (2017). The effect of light quality on growth and development of in vitro plantlet of Stevia rebaudiana Bertoni. Sugar Tech, 19(3), 331336. http://dx.doi.org/10.1007/s12355-016-0459-5. 
Roman, H., Girault, T., Barbier, F., Péron, T., Brouard, N., Pěnčík, A., Novák, O., Vian, A., Sakr, S., Lothier, J., Gourrierec, J. L., \& Leduc, N. (2016). Cytokinins are initial targets of light in the control of bud outgrowth. Plant Physiology, 172(1), 489-509. PMid:27462085. http://dx.doi.org/10.1104/pp.16.00530.

Silva, S. T., Bertolucci, S. K. V., da Cunha, S. H. B., Lazzarini, L. E. S., Tavares, M. C., \& Pinto, J. E. B. P. (2017). Effect of light and natural ventilation systems on the growth parameters and carvacrol content in the in vitro cultures of Plectranthus amboinicus (Lour.) Spreng. Plant Cell, Tissue and Organ Culture, 129(3), 501-510. http://dx.doi.org/10.1007/s11240-017-1195-6.

Singh, A. S., Jones, A. M. P., Shukla, M. R., \& Saxena, P. K. (2017). High light intensity stress as the limiting factor in micropropagation of sugar maple (Acer saccharum marsh.). Plant Cell, Tissue and Organ Culture, 129(2), 209-221. http://dx.doi.org/10.1007/s11240-017-1170-2.

Smirnakou, S., Ouzounis, T., \& Radoglou, K. (2016). Effects of continuous spectrum LEDs used in indoor cultivation of two coniferous species Pinus sylvestris L. and Abies borisii-regis Mattf. Scandinavian Journal of Forest Research, 31, 115-122.

Souza, D. M. S. C., Xavier, A., Otoni, W. C., Miranda, N. A., \& Maggioni, J. H. (2018). Light quality in the in vitro introduction of Corymbia hybrid clones. Revista Árvore, 42(6), 1-9. http://dx.doi.org/10.1590/1806-90882018000600004.

Souza, D. M. S. C., Fernandes, S. B., Avelar, M. L. M., Frade, S. R. P., Molinar, L. V., Gonçalves, D. S., \& Brondani, G. E. (2019). Mixotrophism effect on in vitro elongation and adventitious rooting of Eucalyptus dunnii. Cerne, 25(4), 394-401. http://dx.doi.org/10.1590/01047760201925042638.

Taiz, L., \& Zeiger, E. (2013). Fisiologia vegetal (5. ed., 719 p.). Porto Alegre: Artmed.

Trueman, S. J., Hung, C. D., \& Wendling, I. (2018). Tissue culture of Corymbia and Eucalyptus. Forests, 9(2), 1-42. http://dx.doi.org/10.3390/f9020084.

Xiao, Y., Niu, G., \& Kozai, T. (2011). Development and application of photoautotrophic micropropagation systems. Plant Cell, Tissue and Organ Culture, 105(2), 149-158. http://dx.doi.org/10.1007/s11240-0109863-9.

Author contributions: DMSCS: conceptualization, data curation, formal analysis, methodology, writing - original draft, writing - review \& editing; SBF: conceptualization, data curation, formal analysis, methodology, writing original draft; MLMA: conceptualization, data curation, formal analysis, methodology, writing - original draft, writing - review \& editing; SRPF: formal analysis, methodology, writing - original draft; LVM: formal analysis, methodology, writing - original draft; DSG: formal analysis, methodology, writing - original draft; JEBPP: supervision, validation, visualization, writing - review \& editing; GEB: supervision, validation, visualization, writing - review \& editing. 